\title{
Seasonal changes in body mass, body composition and food requirements in wild migratory birds
}

\author{
BY IAN SCOTT, P. IAN MITCHELL AND PETER R. EVANS \\ Department of Biological Sciences, University of Durham, Science Laboratories, South Road, \\ Durham DH1 3LE
}

Some species of small migrant songbirds and shorebirds undergo seasonal changes in body mass which are proportionately greater and more rapid than those known in any other adult vertebrates. Within a 2-3-week period before migration they may double in total body mass, but after 2-3 d of flight return to starting mass (Davidson \& Evans, 1988; Alerstam \& Lindstrom, 1990). These changes occur largely through the deposition and utilization of fat as fuel for sustained flight. However, it has been accepted for some time that many species of goose store not only fat but also protein before spring migration (McLandress \& Raveling, 1981). Although earlier studies of most migratory songbirds suggested that fat was the only component that varied (e.g. Connell et al. 1960; Odum et al. 1964), more recent information shows that in several species lean mass also increases before migration (for summary, see Piersma, 1990).

In the present paper we review information on seasonal changes in body mass and body composition of migrating birds and how they are brought about in terms of nutrient supplies; and we discuss what sets the limits to these changes and how body mass may be regulated both proximately and ultimately.

\section{SEASONAL CHANGES IN BODY MASS AND BODY COMPOSITION}

Fig. 1 shows the typical pattern of changes in body mass of an adult migratory songbird or shorebird of a species that moves within the Northern Hemisphere from breeding areas at high latitudes to non-breeding areas further south. This model assumes that a bird leaves the breeding grounds as soon as its young are independent in late summer and travels to an area where it (1) moults out of breeding plumage, (2) stays during the winter, (3) moults into breeding plumage in spring, and then (4) migrates northwards to breed. Three points are worthy of note: (1) its peak body mass before migration southwards in late summer is lower than before the northward return migration, (2) its midwinter peak in body mass is less than before either southward or northward migration, (3) the rate of increase in its body mass from autumn to winter is slower than during preparation for migration. Fig. 2 shows this pattern of change in the body mass of an arctic-breeding shorebird, the sanderling (Calidris alba), caught during the nonbreeding season at Teesmouth, northeast England. Fig. 3 shows the changes in its body composition.

Recent studies on shorebirds have shown that only part of the increase in total mass before migration is composed of fat; there is also a significant increase in mass of flight muscles, water and other non-skeletal components of lean mass (Davidson \& Evans, 1988; Piersma \& Jukema, 1990; Evans, 1992; Lindstrom \& Piersma, 1993). Table 1 illustrates this for knot (Calidris canutus) caught during May 1986 at Balsfjord in north Norway, a refuelling area on the spring migration route between the North Sea coasts, 


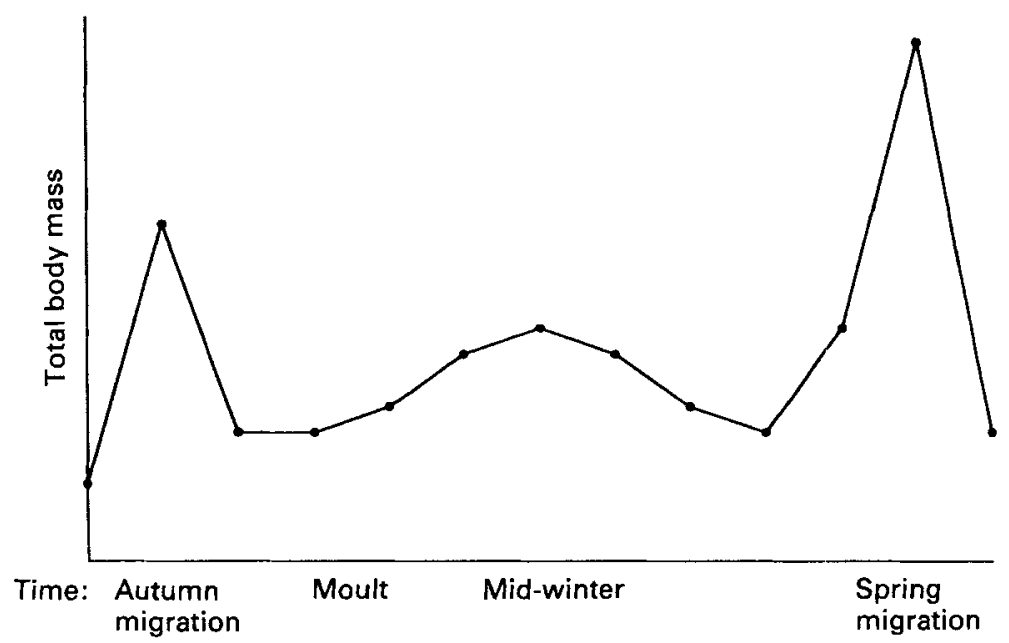

Fig. 1. Schematic diagram to illustrate the typical pattern of changes in body mass of an adult migratory songbird or shorebird of a species that moves within the Northern Hemisphere from breeding areas at high latitudes to non-breeding areas further south. This model assumes that a bird leaves the breeding grounds as soon as its young are independent in late summer and travels to an area where it (1) moults out of breeding plumage, (2) stays during the winter, (3) moults into breeding plumage in spring, then (4) migrates northwards to breed. (Changes in body mass during the breeding season are not shown.)

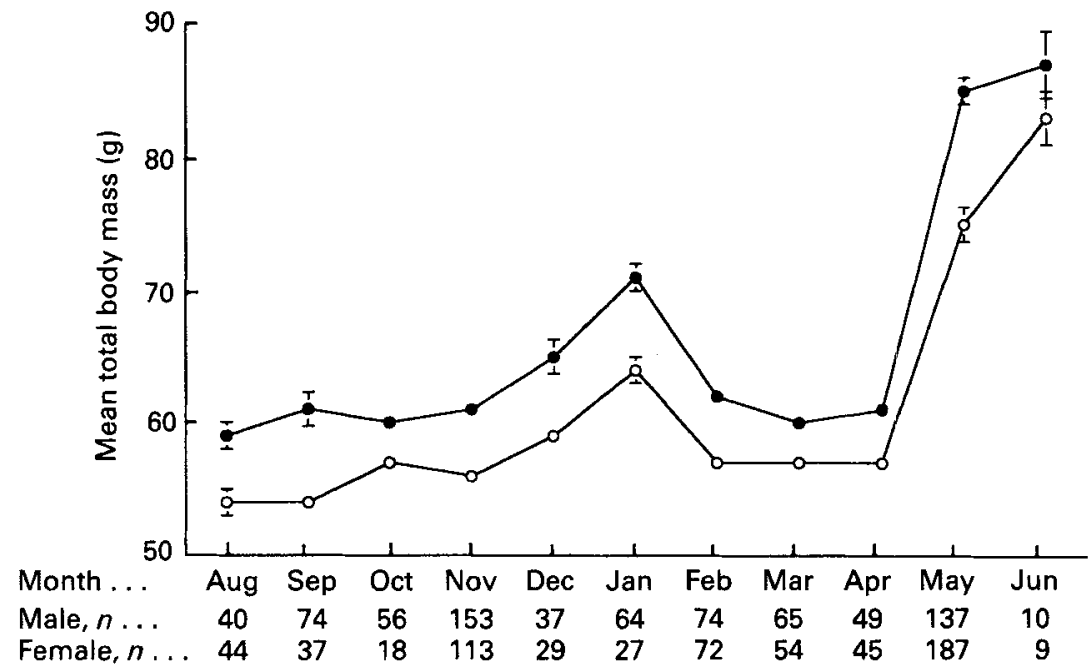

Fig. 2. Seasonal variation in mean body mass of adult sanderling (Calidris alba) caught during the non-breeding season at Teesmouth between 1979 and 1989. Values are means with $2 \times$ the standard error of the sample mean represented by vertical bars. (O), Males; (O), females.

where the species overwinters, and Greenland or arctic Canada where it breeds. Hypertrophy of the flight muscles accounts for a considerable proportion of the increase in total lean mass (total body mass minus mass of fat) during refuelling. Such hypertrophy could have many functions. These include: providing extra power to 


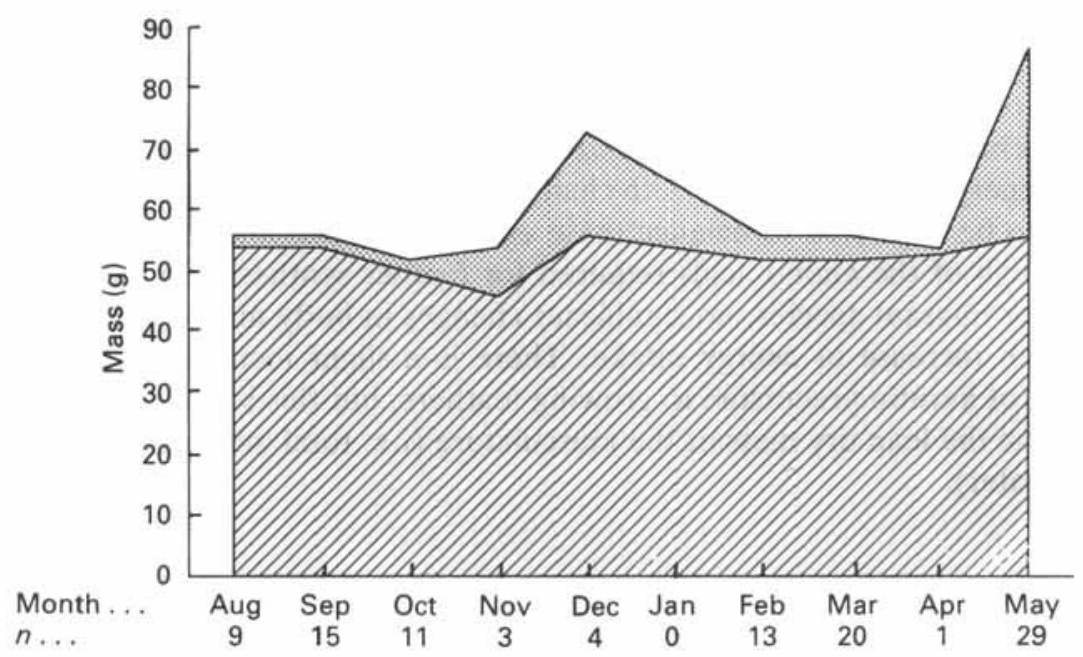

Fig. 3. Seasonal variation in mass of fat $(\square)$ and total lean mass $(\square)$ of sanderling (Calidris alba) caught at Teesmouth as revealed by carcass analysis.

Table 1. Body mass $(\mathrm{g})$ and body composition $(\mathrm{g})$ of knot (Calidris canutus) caught during May 1986 at Balsfjord, north Norway, a refuelling area on the spring migration. Data are taken from Evans (1992)

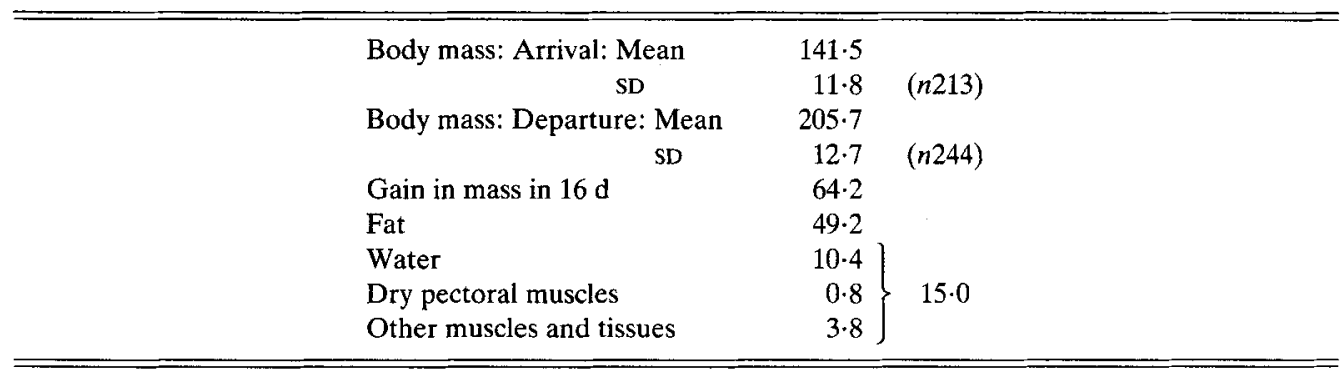

provide for flight at take-off when a substantial load of fat is being carried as fuel; to provide a store of protein to allow for normal turnover of protein during sustained flight; to provide a reserve of protein to be used immediately after migration if feeding conditions are unpredictable at the arrival site; to provide a store of amino acids to facilitate rapid egg formation after arrival on the breeding grounds (Evans et al. 1992). For several species of goose, accumulation of sufficiently large reserves of fat and protein in spring is important if birds are to breed successfully that year (Ankney \& MacInnes, 1978; Drent \& Daan, 1980; Davies \& Cook, 1983; Ankney, 1984). Furthermore, shorebirds of above-average body mass for their size during spring migration survive better to subsequent years (Davidson \& Wilson, 1994).

\section{FEATHER MOULT}

Moult has often been considered to be a period of nutritional stress (King \& Murphy, 1985). Obtaining the S-containing amino acids in sufficient quantity to allow rapid 
synthesis of the feather protein keratin was thought to impose a nutritional bottle-neck. However, the work of Murphy \& King (1990) demonstrated that because feather synthesis occurs throughout the day and night, even though food may be ingested only by day, protein reserves must be synthesized and broken down continuously and that there are high energy costs associated with changes in $\mathrm{N}$ metabolism. Food intake during moult appears to be regulated to balance these energy demands and, thereby, provides more than enough of the amino acids required for feather synthesis. In most birds, whether resident or migrant species, no significant changes in body mass occur during moult, in spite of an increase in energy intake. There is a slight increase in blood volume for transport of keratin precursors to growing feathers, but this is often matched by a slight decrease in the lean dry mass of the musculature (i.e. total mass minus the mass of both fat and water).

\section{HOW ARE INCREASES IN BODY MASS ACHIEVED?}

The possible mechanisms used to achieve rapid rates of increase in body mass are: (1) hyperphagia (raised food intake levels); (2) lower energy expenditure; this might result from any of the following: a reduction in metabolic rate, a decrease in activity, a decrease in thermal conductance (either physiologically or behaviourally), or use of a more thermally-suitable environment; (3) change in diet selection; (4) an increase in absorption efficiency of energy and nutrients from food.

Studies of diet selection on captive birds have focused chiefly on insectivorous songbirds in late summer before migration and on seed-eating songbirds before spring migration in winter (e.g. King, 1961 $a, b$; Bairlein, 1985, 1990). Early studies by King \& Farner $(1959,1965)$, chiefly on the white crowned sparrow (Zonotrichia leucophrys), indicated that the extra energy required for fat deposition in spring was brought about by hyperphagia. They detected no major increase in the proportion of energy intake that was metabolized, nor any decrease in locomotor activity. However, they did not allow any change in choice of diet which may occur in the wild. More recent studies by Bairlein (1990) on the preparation for late summer migration in an insectivorous species, the garden warbler (Sylvia borin), found some evidence for an increase in assimilation efficiency and also for a shift from an insect-rich to a fruit-dominated diet in autumn in both captive and wild birds. (Such a switch is not possible in spring as there is very little fruit available.) Rates of fat deposition differed in birds kept on different fruit diets. The use of fruits by wild songbird migrants in late summer and early autumn has been known for some time (see Evans, 1966). Lowering of daily energy expenditure has not been detected. Indeed, metabolic rate has been found to increase in captive knot at such times (Cadee, 1992) and feeding activity (feeding rate) increases in wild redshank (Tringa totanus) and ringed plover (Charidrus hiaticula; I. Scott, unpublished results). Furthermore, increase in feeding rate is associated in these species with an increase in locomotor activity and, thus, in energy requirements.

Of the other mechanisms suggested previously as methods by which an increase in daily net energy gain might be achieved during premigratory periods, thermal conductance probably does not decrease before spring migration as breeding plumage is generally not as dense as winter plumage. Some birds stop to re-fuel during migration at sites which have more favourable thermal environments than the departure sites, especially in late summer. Those birds which both winter and deposit premigratory fat at 
Table 2. Food availability, foraging activity, average staging time, and body weight increase of dunlins (Calidris alpina) in the Sidi Moussa estuary, Morocco, in March 1981 and April 1982. Data taken from Piersma (1988)

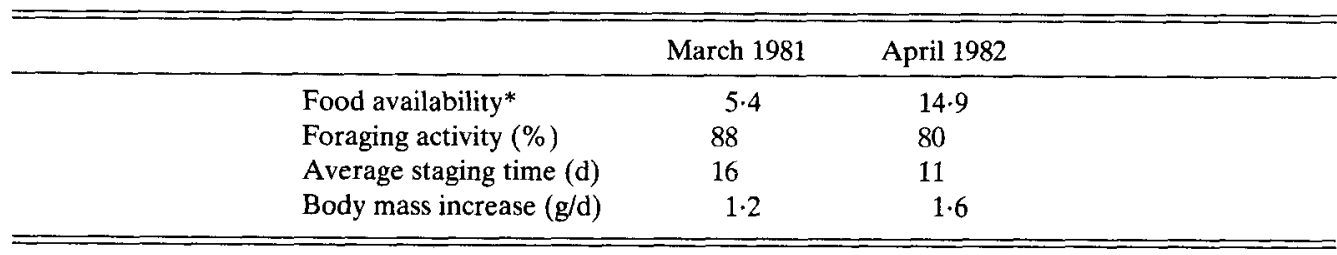

* $\mathrm{g}$ of the most important prey (the ragworm; Nereis diversicolor) $/ \mathrm{m}^{2}$.

the same site will enter more thermally-favourable conditions as temperature at the site increases. Nevertheless, reduced daily energy expenditure is not a necessary or even an important condition for providing the time to allow fat deposition.

\section{WHAT SETS THE LIMITS TO FAT DEPOSITION?}

We have indicated previously that fat deposition during premigratory fattening can occur very rapidly; indeed one individual ringed plover of the race tundrae, caught twice at Teesmouth during the same spring, increased its body mass from 55 to $70 \mathrm{~g}(27 \%)$ in $4 \mathrm{~d}$ (I. Scott, unpublished results).

The question of what limits the rate of fat deposition needs to be addressed. It has been claimed (Kirkwood, 1983), and since then generally assumed (we believe erroneously), that levels of growth observed in the wild are generally physiologically limited. Kirkwood (1983) produced an allometric equation based on the observed maximum food intake rates of endotherms of different masses under conditions of high energy demand. This equation has been used by some authors to predict maximum fat deposition rates (for example, see Lindstrom, 1990). However, Kirkwood's (1983) equation, predicting the maximum rate of growth of homeotherms, is not appropriate for calculating maximum rates of fat deposition as it assumes an energy density of tissue gain of $8.5 \mathrm{~kJ} / \mathrm{g}$ tissue (i.e. that found for growing chicks), whilst the energy density of fat is 39 $\mathrm{kJ} / \mathrm{g}$ (Schmidt-Nielson, 1985), or if we assume that 33\% of the tissue deposited before migration is fat-free (Lindstrom \& Piersma, 1993), it is $28 \mathrm{~kJ} / \mathrm{g}$. Kirkwood's equation is not appropriate, therefore, for predicting the maximum rate of increase of total body mass.

We suggest that as wild birds can adjust gut morphology to suit food type and volume (Goss, 1978) they are likely to have evolved the ability to increase gut length and, therefore, the rate of nutrient absorption as and when required. This would push the physiological limits upwards. Although we do not dispute that there must be a theoretical upper limit to the rate of food intake by an animal in relation to its size, we speculate that perhaps food is never sufficiently abundant (or that there is never enough feeding time) to cause a bird preparing for migration to reach this physiological limit.

We can test this hypothesis, first by examining whether decreased rates of food intake occurred in the field in situations where the food abundance was low, and second by comparing the maximum rates of increase in body mass or mass of fat in captive birds fed ad lib. with those of birds in the wild. Table 2 shows data for dunlin (Calidris alpina) refuelling on the Sidi Moussa estuary, Morocco during March 1981 and April 1982 (from 
Table 3. Maximum recorded daily body mass gains of wild and captive shorebirds

\begin{tabular}{lcccc}
\hline \hline & \multicolumn{2}{c}{ Change } & \multicolumn{1}{c}{$\begin{array}{c}\text { Predicted } \\
\text { change (g) }\end{array}$} \\
\cline { 2 - 4 } Species & $\mathrm{g}$ & $\%$ & 6 \\
Redshank (Tringa totanus): Captive & 6 & 4 & 6 \\
Wild & 1 & 1 & 7 \\
Knot (Calidris canutus): Captive & 9 & 5 & 6 \\
Wild & 4 & 3 & 3 \\
Ringed plover (Charidrus hiaticula): Captive & 4 & 7 & - \\
Sanderling (Calidris alba): Captive & Wild & 4 & 7 & 3 \\
Wild & - & - & 5 & 3 \\
\hline \hline
\end{tabular}

* Predicted values are calculated using a modified version of Kirkwood's (1983) allometric equation of maximum food intake with body mass.

Piersma, 1988). As may be seen, in the year when the prey species were less abundant the bird's foraging activity was higher, their mean staging time was longer and the rate of increase in their body mass was lower.

The maximum rates of increase in body mass for four species of shorebird are given in Table 3. Those for the captive shorebirds are the highest rates recorded for any individual of that species held in captivity and fed ad lib. on a diet of blowfly (Calliphora $s p$.) larvae and pelleted trout food. For wild birds, values for redshank and ringed plover are also the highest rates recorded for any individual, based on recaptured birds, whilst those for knot and sanderling are the highest rates of increase in body mass obtained from the mean body masses of catches made within the same season. This latter method probably leads to a slight underestimation of the maximum rates, although the error should be small because population turnover at staging posts in these species is not high. In ringed plover the maximum rates are equal in captive and wild individuals, whilst in redshank and knot the rates of increase in mass in captive birds were faster than those measured in the wild (data for captive sanderling are not yet available). Thus, we conclude that in at least two of the three species there is evidence for environmental limitation in the rate of body mass gain. We do not know of a study which has shown convincingly that physiological limitation is important. We note also that the theoretical maximum rate of gain in mass (derived from Kirkwood (1983), but corrected by using the average energy density of fat and other tissues deposited by adult birds, see p. 525) was exceeded by $25 \%$ in the case of captive ringed plover and by $28 \%$ in captive knot.

\section{HOW IS BODY MASS REGULATED?}

It is clear that birds do not maintain body mass at the highest possible levels all year round. If it is supposed that active regulation occurs around different set points no higher than 'necessary' at different seasons, then we must assume that there is an increased cost associated with being heavy (see Witter \& Cuthill, 1993). The increased risk of predation is often cited as a potential cost to heavier birds and relies on the theoretical prediction that birds are less manoeuvrable when fat. However, the relationship between predation risk and fat load has yet to be shown directly. Nevertheless, the pattern of a pronounced mid-winter peak in body mass (and fat load) in shorebirds and songbirds has been 


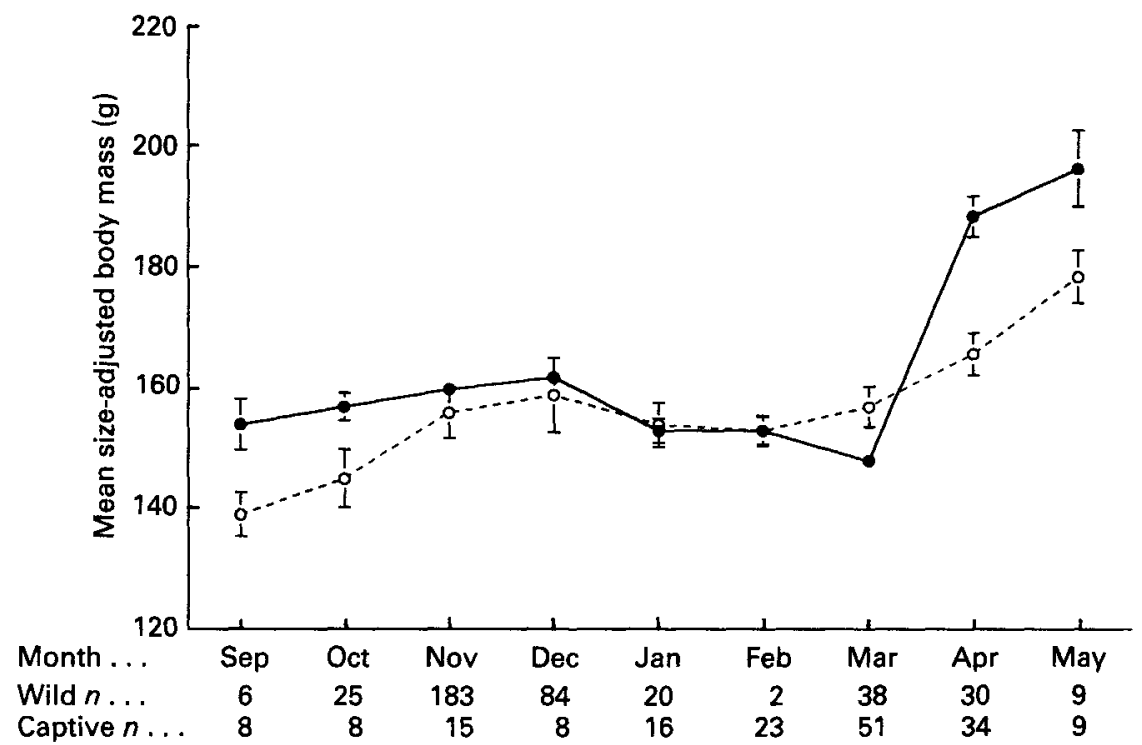

Fig. 4. Mean monthly body mass (size adjusted) of captive redshank (Tringa totanus); (1992-3; $\bigcirc---\bigcirc)$ and wild redshank (1992-3; - ) at Teesmouth. Values are means with $2 \times$ the standard error of the sample mean represented by vertical bars. Spearman Rank Correlation; $r_{\mathrm{s}}=0.61, P<0 \cdot 05, n=9$.

claimed to demonstrate that regulation is occurring (Pienkowski et al. 1979). It has been claimed that the build up of reserves in autumn is an insurance against the possibility of encountering severe weather conditions in winter, which reduce food availability and lead to negative energy balance (Evans \& Smith, 1975; Dugan et al. 1981). These authors suggested that, following mid-winter, reserves are allowed to fall as the chance of encountering severe weather decreases as winter progresses. The cost of being heavy (fat) was assumed to remain constant. This hypothesis has found both theoretical (Lima, 1986) and field-based support (Davidson, 1981; Rogers, 1987). We tested this hypothesis in redshank by comparing the body masses of birds held in captivity through the winter with those of the same species (redshank) in the wild. We supposed that if redshank (which spend the non-breeding season in mid-northern latitudes) actively regulate their body mass and follow a seasonally varying optimum, then the pattern of body mass change of birds kept in captivity under a photoperiod regime mimicking that in the wild would follow that of the wild population. If redshank do not regulate body mass in the wild, then birds held in captivity should maintain the maximum body mass possible throughout the season. The results presented in Fig. 4 have been size-adjusted to allow for seasonal movements of two populations of redshank of differing body sizes to and from the Tees estuary. The body masses of captives closely follow those of birds in the wild. There is no significant difference in the magnitude of the body masses between the two groups, (Student's $t$ test; $T 1.37$, df $16, P<0.05$ ) and the patterns of body mass change are significantly positively correlated (Spearman's Rank Correlation; $r_{\mathrm{s}} 0.61, n 9$, $P<0 \cdot 05)$.

We conclude from this study that redshank that spend the non-breeding season on the north-east coast of England are able to regulate body mass internally, independently of food supply. This implies that there must be a cost associated with carrying extra tissue 
Table 4. Body masses (corrected for time between capture and weighing) of knot (Calidris canutus) at Balsfjord, north Norway. Data are taken from Evans (1992)

\begin{tabular}{|c|c|c|c|c|}
\hline \multirow[b]{2}{*}{ Day } & \multirow[b]{2}{*}{$n$} & \multicolumn{2}{|c|}{ Body mass (g) } & \multirow[b]{2}{*}{$\mathrm{CV}$} \\
\hline & & Mean & SD & \\
\hline 11 May & 213 & 141.5 & $11 \cdot 8$ & $8 \cdot 3$ \\
\hline 13 May & 55 & 144.8 & $10 \cdot 5$ & $7 \cdot 3$ \\
\hline 27 May & 244 & $205 \cdot 7$ & $12 \cdot 7$ & $6 \cdot 2$ \\
\hline 28 May & 43 & $185 \cdot 2$ & $18 \cdot 0$ & 9.7 \\
\hline
\end{tabular}

$\mathrm{CV}, \mathrm{SD} / \mathrm{mean} \times 100(\%)$.

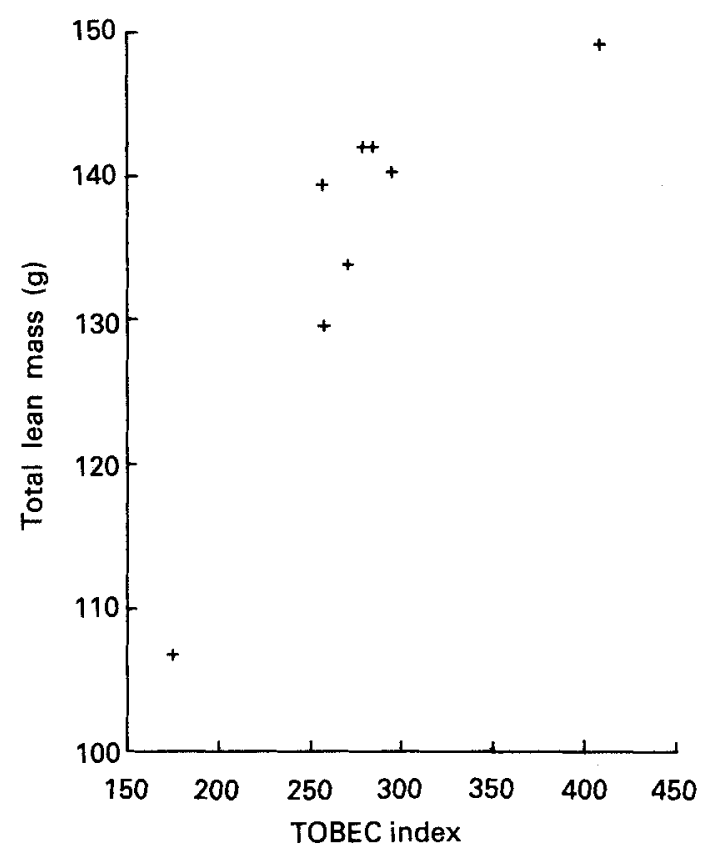

Fig. 5. Intraspecific relationship between total body electrical conductivity (TOBEC) index and total lean mass for redshank (Tringa totanus). The line of best fit is a second-order polynomial; $r^{2}=0.92, P<0.01, n=8$. Predicted total lean mass $(\mathrm{g})=3.623+0.765 \mathrm{TI}-0.001 \mathrm{TI}^{2}$, where $\mathrm{TI}$ is TOBEC index.

relative to an individual's body size. Such a cost could be an increased risk of predation, as suggested earlier, but may simply be the cost of carrying (especially flying with) an additional load (Witter \& Cuthill, 1993).

If birds do regulate their total body masses they must have the ability to know how heavy they are. Information from knot at the Balsfjord refuelling area in 1986 is shown in Table 4. On 27 May the main departure of knot took place and these data show that a sample of birds caught on the following day from amongst those few that remained were significantly lighter, thus indicating that birds must normally reach a set point of total mass, or mass of fat, before continuing on migration.

Further to our studies of changes of total mass of redshanks outlined previously, we have also monitored their body composition both in captivity and in the wild using a 

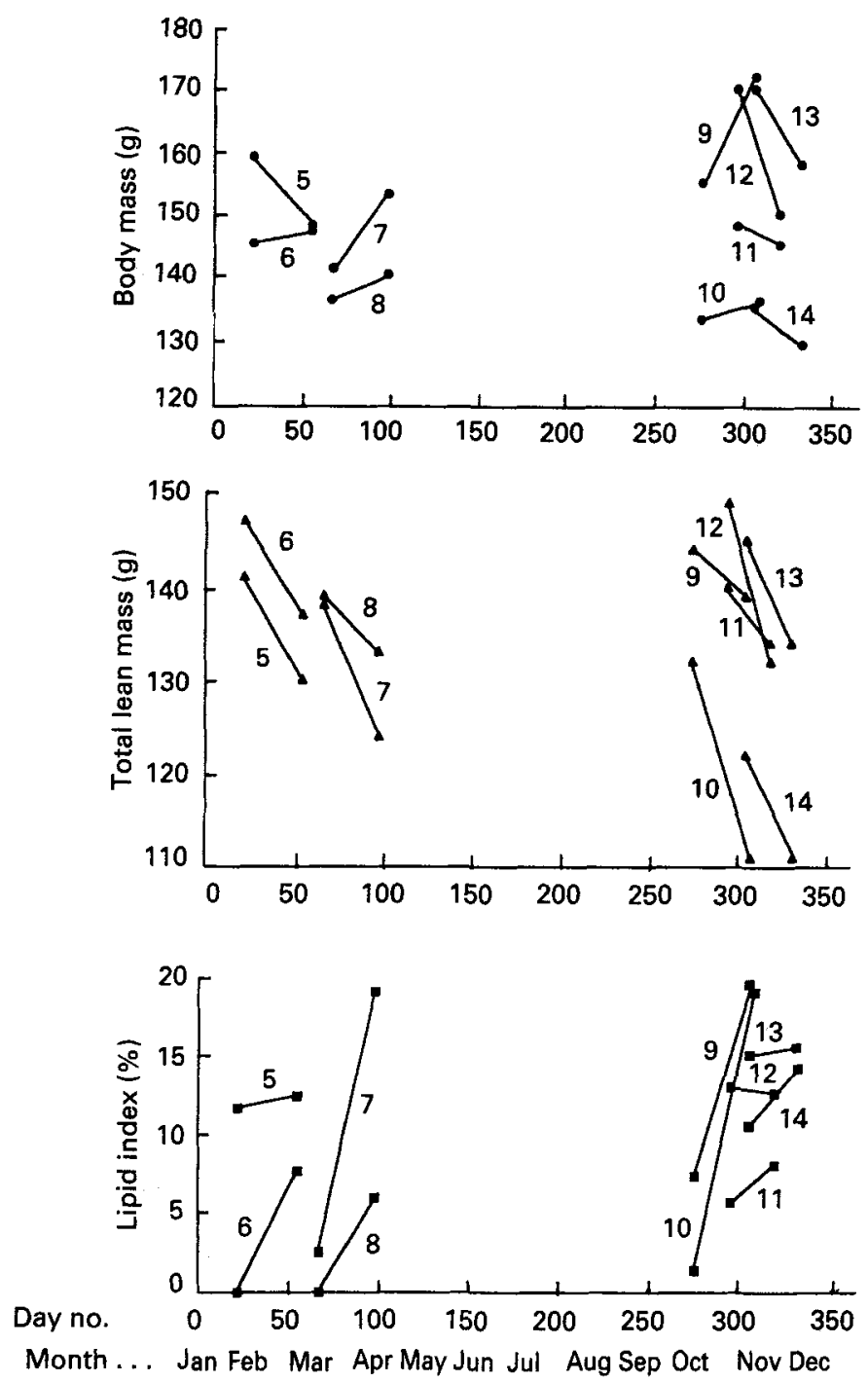

Fig. 6. Change in body mass and body composition of redshanks (Tringa totanus) brought into captivity on different dates. (captivity and 1 month later. Lipid index is defined as predicted fat mass divided by total body mass $\times 100$.

non-invasive technique, i.e. total body electrical conductivity (TOBEC). The TOBEC technique relies on the principle that fat conducts electricity much less well than do the lean tissues that make up the rest of the body (Pethig, 1979); thus, the conductivity of an individual is proportional to its lean tissue mass. The use of the TOBEC method to obtain estimates of total lean mass has been assessed in a number of studies (for example, see Walsberg, 1988; Castro et al. 1990; Scott et al. 1991). Scott et al. (1991) found that intra-specific equations give more accurate predictions of total lean mass than do interspecific equations; from a species-specific equation for the starling (Sturnus 
vulgaris) we found that the mean error of prediction was only $0.9 \mathrm{~g}$, i.e. $1 \cdot 2 \%$. The calibration curve that we established for redshank by analysis of body composition of a sample taken under licence is shown in Fig. 5. Values for total lean mass were obtained by Soxhlet extraction of dry carcasses with chloroform as solvent. When we compared the values, predicted from TOBEC measurements, for body composition of captive and wild redshank, we observed that birds in captivity had lower levels of predicted total lean mass but higher levels of predicted fat mass when compared with birds in the wild. However, as shown in Fig. 4, the body masses of birds in captivity did not differ significantly from those in the wild. Samples of birds were taken into captivity at several different dates (Fig. 6). At 1 month after the appropriate date, each redshank's predicted total lean mass had decreased significantly (paired $t$ test; $T 7 \cdot 30, P<0 \cdot 001$ ), whilst its predicted fat mass, in most individuals, had increased significantly (paired $t$ test; $T 2.74$, $P<0.05$ ), although total body mass had not changed significantly (paired $t$ test; $T 0.39$, $P>0.05)$. In order to verify that the changes in body components in captive birds described previously did not occur in the birds sampled from the wild, we calculated the differences between the predicted total lean body mass of each captive bird and the mean of the predicted total lean mass of birds sampled in the wild at the same date: (1) when the individual was taken into captivity, (2) 1 month later. After 1 month in captivity the difference between captive and wild birds in predicted total lean mass had become significantly larger and more negative (Wilcoxon paired $t$ test; $P<0 \cdot 05$ ), i.e. the captive birds had lost lean tissue in relation to their conspecifics in the wild.

Thus from our findings, we conclude that in at least one bird species individuals appear to regulate their total body mass irrespective of body composition; that is to say, they weigh themselves. The mechanism through which this is achieved is not understood at present.

\section{REFERENCES}

Alerstam, T. \& Lindstrom, A. (1990). Optimal bird migration: the relative importance of time, energy and safety. In Bird Migration: The Physiology and Ecophysiology, pp. 331-351 [E. Gwinner, editor]. Berlin and Heidelberg: Springer.

Ankney, C. D. (1984). Nutrient reserve dynamics of breeding and moulting Brant. Auk 101, 361-370.

Ankney, C. D. \& MacInnes, C. D. (1978). Nutrient reserves and reproductive performance of female lesser snow geese. $A u k$ 95, 459-471.

Bairlein, F. (1985). Efficiency of food utilization during fat deposition in the long distance migratory Garden Warbler Sylvia borin. Oecologia 68, 118-125.

Bairlein, F. (1990). Nutritional adaptations to fat deposition in the long distance migratory garden warbler Sylvia borin. Proceedings of the International Ornithological Congress XX, 2149-2158.

Cadee, N. (1992). Seasonal changes in metabolic rate in Knots in relation to migratory performance. MSc Thesis, University of Groningen.

Castro, G., Wunder, B. A. \& Knopf, F. L. (1990). Total body electrical conductivity (TOBEC) to estimate total body fat of free-living birds. Condor $92,496-499$.

Connell, C. E., Odum, E. P. \& Kale, H. (1960). Fat-free weights of birds. Auk 77, 1-9.

Davidson, N. C. (1981). Survival of shorebirds (Charadrii) during severe weather: The role of nutritional reserves. In Feeding and Survival Strategies of Estuarine Organisms, pp. 231-249 [N. V. Jones and W. J. Wolff, editors]. New York: Plenum Press.

Davidson, N. C. \& Evans, P. R. (1988). Prebreeding accumulation of fat and muscle protein by arctic-breeding shorebirds. Proceedings of the International Ornithological Congress XIX, 342-352.

Davidson, N. C. \& Wilson, J. R. (1994). Journal of Avian Biology (In the Press).

Davies, J. C. \& Cooke, F. (1983). Annual nesting productivity in Snow Geese: prairie droughts and arctic springs. Journal of Wildlife Management 47, 291-296. 
Drent, R. H. \& Daan, S. (1980). The prudent parent: energetic adjustments in avian breeding. Ardea 68 , 225-252.

Dugan, P. J., Evans, P. R., Goodyer, L. R. \& Davidson, N. C. (1981). Winter fat reserves in shorebirds: disturbance of regulated levels by severe weather conditions. Ibis 123, 359-363.

Evans, P. R. (1966). Migration and orientation of passerine night-migrants in northeast England. Journal of Zoology, London 150, 319-369.

Evans, P. R. (1992). The use of Balsfjord as a staging post by Knot during spring migration: Fat deposition, muscle hypertrophy and flight strategies. Wader Study Group Bulletin 63, Suppl., 126-128.

Evans, P. R., Davidson, N. C., Uttley, J. D. \& Evans, R. D. (1992). Premigratory hypertrophy of flight muscles: an ultrastructural study. Ornis scandinavica 23, 238-243.

Evans, P. R. \& Smith, P. C. (1975). Studies of shorebirds at Lindisfarne, Northumberland. 2. Fat and pectoral muscle as indicators of body condition in the Bar-tailed Godwit. Wildfowl 26, 64-76.

Goss, R. J. (1978). The Physiology of Growth. New York: Academic Press.

King, J. R. (1961a). On the regulation of vernal moult premigratory fattening in the white crowned sparrow. Physiological Zoology 34, 145-157.

King, J. R. (1961b). The bioenergetics of vernal premigratory fat deposition in the white crowned sparrow. Condor 63, 128-142.

King, J. R. \& Farner, D. S. (1959). Premigratory changes in body weight and fat in wild and captive white crowned sparrows. Condor 61, 315-324.

King, J. R. \& Farner, D. S. (1965). Studies of fat deposition in migratory birds. Annals of the New York Academy of Sciences 131, 422-440.

King, J. R. \& Murphy, M. E. (1985). Periods of nutritional stress in the annual cycle of endotherms: fact or fiction? American Zoology 25, 955-964.

Kirkwood, J. K. (1983). A limit to metabolisable energy intake in mammals and birds. Comparative Biochemistry and Physiology 75A, 1-3.

Lima, S. L. (1986). Predation risk and unpredictable feeding conditions: Determination of body mass in birds. Ecology 67, 377-385.

Lindstrom, A. (1990). Stop over ecology of migrating birds. PhD Thesis, Lund University, Sweden.

Lindstrom, A. \& Piersma, T. (1993). Mass changes in migrating birds: the evidence for protein storage re-examined. Ibis $\mathbf{1 3 5}, 70-78$.

McLandress, M. R. \& Raveling, D. (1981). Changes in diet and body composition of Canada Geese before spring migration. Auk 98, 65-79.

Murphy, M. E. \& King, J. R. (1990). Nutritional aspects of avian moult. Proceedings of the International Ornithological Congress XX, 2186-2193.

Odum, E. P., Rogers, D. T. \& Hicks, D. L. (1964). Homoeostasis of the non-fat components of migrating birds. Science 143, 1037-1039.

Pethig, R. (1979). Dielectric and Electrical Properties of Biological Materials. Chichester: John Wiley.

Pienkowski, M. W., Lloyd, C. S. \& Minton, C. D. T. (1979). Seasonal and migrational weight changes in Dunlins. Bird Study 26, 134-148.

Piersma, T. (1988). Hop, skip or jump? Constraints on migration of Arctic waders by feeding, fattening and flight speed. Wader Study Group Bulletin 53, 6-7.

Piersma, T. (1990). Pre-migratory 'fattening' usually involves more than the deposition of fat alone. Ringing and Migration 11, 113-115.

Piersma, T. \& Jukema, J. (1990). Budgeting the flight of a long distance migrant: changes in nutrient reserve levels of Bar-tailed Godwits at successive staging sites. Ardea 78, 221-236.

Rogers, C. M. (1987). Predation risk and fasting capacity: Do wintering birds maintain optimal body mass? Ecology 68, 1051-1061.

Schmidt-Nielson, K. (1985). Animal Physiology Adaptation and Environment. Cambridge: Cambridge University Press.

Scott, I., Grant, M. \& Evans, P. R. (1991). Estimation of fat-free mass of live birds: use of total body electrical conductivity (TOBEC) measurements in studies of single species in the field. Functional Ecology 5. 314-320.

Walsberg, G. E. (1988). Evaluation of a non-destructive method for determining fat stores in small birds and mammals. Physiological Zoology 61, 153-159.

Witter, M. S. \& Cuthill, I. C. (1993). The ecological cost of avian fat storage. Philosophical Transactions of the Royal Society 340B, 73-92. 